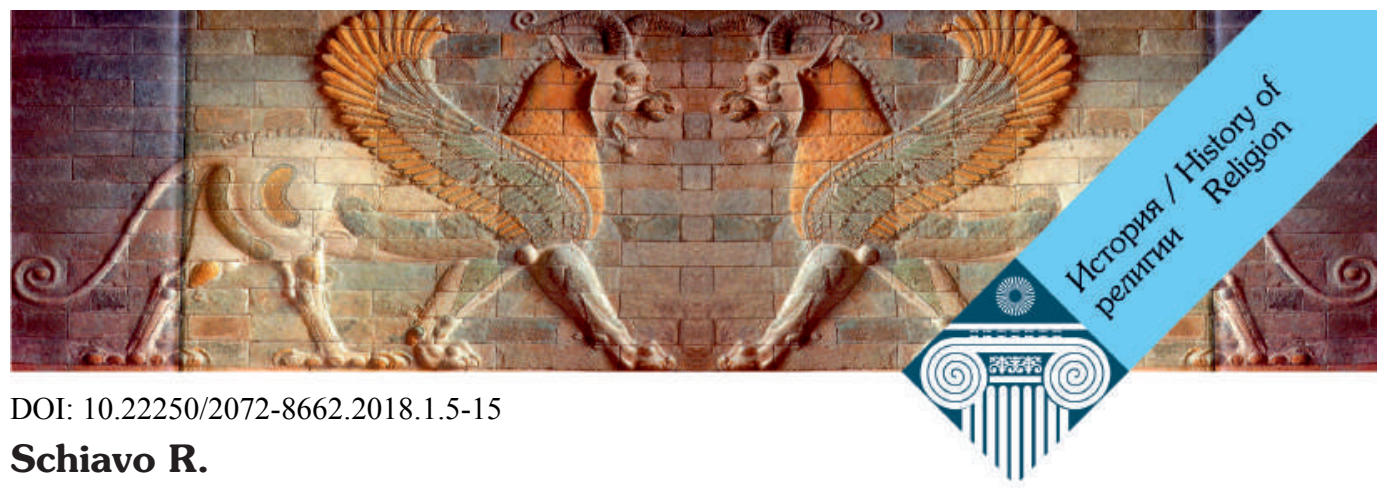

\title{
On the Improper Use of the Label "Shamanism" in Egyptology: Rethinking the Role of the Opening of the Mouth Ritual and the Tekenu Ceremony in Light of Ancestor Worship
}

Abstract. There is some debate about the existence of an "ancient Egyptian shamanism". A number of scholars used such a label to describe religious phenomena relating to the pre and proto-dynastic religion, the Opening of the Mouth Ritual (especially scenes 9 and 10), and the Tekenu ceremony. Moreover, it is possible to identify a certain "evolutionistic" tendency in explaining the two aforementioned rituals as "living fossils" of the Archaic Period. Given That the use of terms "shaman" or

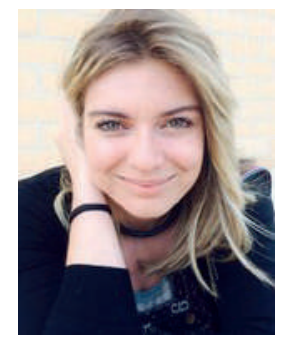
"shamanism" could be problematic if applied to Ancient Egypt, the main aim of the paper is to analyze the data concerning the Opening of the Mouth Ritual scenes 9 and 10 and the Tekenu ceremony in order to understand their function in their historical and sociological context through a comparison with other documents, such as the letters to the dead, the Coffin Texts spells 30-41 and the customary laws concerning inheritance. Finally, it is suggested that both the Opening of the Mouth Ritual and the Tekenu ceremony acted as "double rites of passage", during which not only the deceased became an ancestor, but also the main officiant of the two ceremonies, who was the elder son of the dead, could achieve a new social status as the new chief of the extended family.

Key words: Egyptology, opening of the mouth ritual, Tekenu ceremony, ancestor worship, shamanism

\section{Скьяво P.}

\section{О ненадлежашем испопьзовании \\ термина "шаманизм» в египтопогии: переосмыспение ропи ритуапа отверзения уст и церемонии Текену в свете купьта предков}

Аннотация. Известна дискуссия о существовании «древнеегипетского шаманизма». Некоторые исследователи использовали понятие «шаманизм» для описания религиозных явлений, относящихся к дои протодинастической религии, а именно: ритуала отверзения уст (особенно в сценах 9 и 10) и церемонии Текену. Более того, можно выявить наличие определённой «эволюционистской» тенденции в имеющихся объяснениях этих двух ритуалов как «живых окаменелостей» архаического периода. Основная цель представленной статьи - проанализировать сведения о сценах 9 и 10 ритуала отверзения уст и церемонии Текену с учётом того, что использование терминов «шаман» или «шаманизм» в отношении Древнего Египта является спорным. Для определения функций этих ритуалов их описания рассматриваются в историческом и социальном контекстах в сравнении с другими текстами, такими как письма к мёртвым, заговоры 30-41 из Текстов саркофагов и нормы обычного права о наследовании. В результате делается вывод о том, что и ритуал отверзения уст, и церемония Текену выполняли функции «двойных обрядов перехода», во время которых не только умерший становился предком, но и старший сын покойного, главный участник обеих церемоний, достигал нового социального статуса - становился новым главой семьи.

Кпючевые спова: египтология, ритуал отверзения уст, церемония Текену, культ предков, шаманизм

Рената Скьяво - обладательница степени $\mathrm{PhD}$ (египтология), Лейденский университет, Институт региональных исследований Лейденского университета; ул. Маттиаса де Вришофа, 3, 2311 BZ Лейден, Нидерланды, 2311; renat.schi@gmail.com.

Renata Schiavo - PhD (Egyptology), Leiden University, The Leiden University Institute for Area Studies (LIAS); 3 Matthias de Vrieshof, 2311 BZ Leiden, The Netherlands; renat.schi@gmail.com. 


\section{История религии / History of Religion}

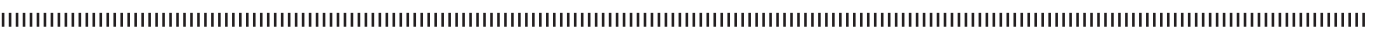

\section{Premises and Aims}

The existence of Egyptian ancestor worship has been denied by specialists for a long time. This could appear as a rather odd fact. The complex treatments reserved for corpses (mummification) and the importance given to burials by ancient Egyptians are well known; and such elements clearly suggest that the dead played an important role in religious belief.

On the other hand, in the Lexikon der Ägyptologie, under the heading «Ahnenkult», written by Dieter Wildung, the following statements can be read: a fully developed Egyptian ancestor worship never existed; only a very restricted quantity of data concerning merely an embryonal state of this belief is known (the so-called letters to the dead or the data concerning the domestic cult at Deir el-Medina);and, although several festivals to praise the dead are well attested to, there are no traces of specific rituals performed for the ancestors [Wildung, 1975, 111-112].

In this regard, it is also essential to underline that a markedly ethnocentric definition of «ancestor» led to a distinction which was excessively strict and unproductive between the labels «cult of the dead» (Totenkult) and «ancestor worship» (Ahnenkult). In fact, if the term «ancestor» is limited exclusively to forebears dead for more than two generations [Wildung, 1975, 111-112], several Egyptian texts and data cannot be considered as an expression of an articulated ancestor worship, since they mainly pertain to the special bond between the deceased father and his living eldest son [Assmann, 1986, 659-664].

Under this point of view, it can be argued that the rise of studies concerning Egyptian ancestor worship was greatly connected to a new definition of «ancestor», indebted to ethnographic comparisons, especially with African cultures. To this regard a paper by Igor Kopytoff furnished a fresh perspective and has been cited in all the first Egyptological works on this topic [Demarée, 1983, 288 and note 40; Baines, 1987, 81 and note 8]. Kopytoff, in fact, describes the ancestors not only as preternatural beings, but also as active members of the same social community of the living [Kopytoff, 1971, 129-142].

Another crucial question could be highlighted: Egyptologists used to give more importance to certain religious phenomena still crucial in modern western cultures - such as the positive underworld and the celestial afterlife - at the expense of other phenomena, like the ones involving ghosts and ancestors. As consequence, most works concerning Egyptian ancestor worship were mainly focused on house-cults. Instead, very little attention was given to funerary and mortuary rituals, probably because there was a certain tendency in connecting them with the post mortem rebirth and a new existence in the celestial afterlife, rather than with a rite of passage to transform a dead in an ancestor [important exceptions: Demarée, 1983, 190-276; Donnat, 2009, 90].

On the other hand, if the label «ancestor worship» has been perceived for a long time as problematic especially with regard to funerary and mortuary rituals, there was and still is - some debate about the existence of an «ancient Egyptian shamanism».

A number of scholars used the term «shamanism» to describe religious phenomena relating to the Opening of the Mouth Ritual (especially scenes 9 and 10), the Tekenu ceremony and the proto-dynastic religion. Moreover, it is possible to identify a certain «evolutionistic» tendency in explaining the aforementioned ritual as a «living fossil» of the archaic period.

It is a common opinion among scholars that the labels «shaman» or «shamanism» could be problematic if used outside the specific context of a narrow euroasiatic zone [Ambasciano, 2014, 164-165]. Thus, the main aim of the present paper is to analyze the data previously labeled as «shamanism», and propose a partially new interpretation in light of the mechanics of Egyptian ancestor worship.

\section{State of the Art}

\subsection{First group of studies regarding so-called Egyptian shamanism}

In Egyptology the term «shamanism» has been predominantly used with regard to the Opening of the Mouth Ritual (OMR), a ceremony performed for the symbolic animation of a sculpture portraying the deceased. The name of the ceremony is cited in both royal and non-royal tombs during the Old Kingdom. However, the very first detailed information dates back to the New Kingdom, when vignettes accompanied by captions relating to such a rite began to be reproduced in tombs, stelae or other artifacts with a certain frequency. Currently, not a single tomb, monument or object is known, in which 


\section{История религии / History of Religion}

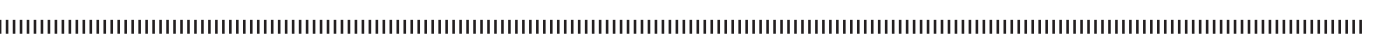

the OMR is entirely represented, and all the scenes were collected for the very first time by Ebernard Otto in 1960 [Otto, 1960].

Although Otto has never used the label «shamanism», it is interesting that for vignettes 9 and 10, he stressed as the captions seem to show a certain «vorklassischen Schich» [Otto, 1960, 57]. In effect, Egyptian funerary and mortuary texts are usually characterized by an astonishing number of mythological associations, where both the deceased and the ritualists are identified with divinities; and where a primary role was played by the gods. Instead, in scenes 9 and 10 we cannot find these traits. First, the text clearly describes the possibility to obtain a contact with the spirits of the dead through a dream induced by a ritualistic sleep. Moreover, not only the main focus is on the relationship between the dead father and his living heir acting as a sem priest, but the gods are totally absent, while a certain role is played by animals, like falcons, bees, a praying mantis and a spider, or other kinds of preternatural beings, such as the shadow ( $\check{s} w . t)$ [Otto, 1960, 55-59].

It is significant in this regard that the first use of the label «shamanism» to describe the OMR appears in 1980 in a work by Beate George devoted to the concept of «shadow» $(\check{s} w . t)$ in the Egyptian religion. George, strongly influenced by Carl Gustave Jung and Mircea Eliade, describes the «shadow» as a kind of vivificating power connected to the sexual energy. And, regarding OMR scene 10, he argues that the sem priest acts here as a shaman. In fact, his duty is to heal the deceased from death through a ritualistic sleep $(\mathrm{kd})$ that he considers as a shamanic trance. Moreover - in his opinion - the sem priest is also able to catch the vivificating power of the dead (the shadow)in order to put it inside the sculpture thanks to the help of animal guides, as attested in several shamanic practices described by Eliade [George, 1970, 87-90].

This «shamanic interpretation» was subsequently adopted by Herman Helck in different works published in the second half of the 80s [Helck 1984; 1987]. Helck not only sustains that the OMR scenes 9 and 10 describe a shamanic trance; but given this starting point, he outlines some insights regarding the historical evolution of the Egyptian religion. Helck's main argumentation is based on the typical dress worn by the sem-priest, a leopard skin. Individuals wearing this kind of garment are attested in several pre- and proto-dynastic artifacts. On the other hand, in proto-dynastic times the iconographic sources relating to the leopard skin wearers are often accompanied by a caption «t tt», probably a title that cannot be etymologically connected with the word «sm», but which shows some affinities with the term «t $3 t y »$, attested in the subsequent historical phases with the meaning of «vizier». Thus, Helck hypothesizes that during the archaic period a shaman-priest played a crucial role assisting the king in his main activities. Only through time, this shamanic figure evolved in two different roles: the vizier and the sem priest who maintained certain shamanic traits as «living fossil» [Helck, 1984].

In this regards, several considerations are needed. First, although Helck's main work on Egyptian shamanism [Helck, 1984] does not have footnotes, Mircea Eliade's influence is undeniable. In fact, Helck sustains that his theory could be particularly interesting since it finally shows the proof of an African shamanism [Helck, 1984, 104]. And, it is well known that in Shamanism: Archaic Technique of Ecstasy by Eliade the data from Africa are almost omitted. Furthermore, even more undeniable is the fact that in Helck's works it is possible to recognize a clear identification of the shamanic practices with the original religion of archaic times typical of Eliade's approach. It is an important aspect, since the shamanic interpretation of the Egyptian proto and pre-dynastic religion is actually accepted by several scholars.

On the other hand, Helck's analysis posed more problems than it solves. He interpreted the actions performed by the sem priest in OMR scenes 9 and 10 as the survival of an archaic shamanic practice; and, as already stressed; one of his main argumentations was based on the leopard skin worn by the sem priest. However, especially in scenes 9 and 10 the vignettes clearly show this priest with another type of dress: a tight garment characterized by several strips (maybe with the intention of depicting linen bandages). In this regard, a paper by Greg Reeder, re-elaborating a previous theory by Alexandre Moret [Moret, 1931, 31 and ff], suggested an explanation connecting scenes 9 and 10 of the OMR with another liturgy attested in a small number of tombs: the Tekenu ritual. 


\section{История религии / History of Religion}

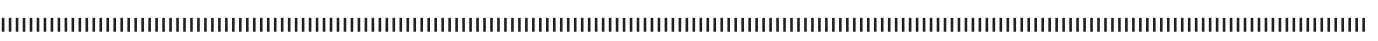

It is a ceremony performed during funerals that involved a strange object, the so-called Tekenu, sometimes represented as a person in a crouching position and wrapped in a large piece of leather ( $\left.m s^{3} k^{3}\right)$ who is about to be transported inside the sepulture, or sleeping inside the tomb. Given the element of sleeping, quite similar to the one of the sem priest, it was hypothesized that it could be identified with a man performing a ritual [Reeder, 1994].

Thus, because of various elements, including the fact that in the Rekhmira tomb (TT 100) both the sleeping Tekenu and the sleeping sem priest are portrayed in the same room, Reeder argued that they could be the same person. This would indicate - in his opinion - that the Tekenu ritual was a kind of preliminary ceremony performed by the sem priest in order to prepare himself for the shamanic trance described in scenes 9 and 10 of the OMR [Reeder, 1994].

In 1998 we have the first work that rejects the label «shamanism» applied to the OMR: a study by Hans-W. Fischer-Elfert. His starting point is that scenes 9 and 10 are concerned with the construction of a sculpture, thus he proposes the following interpretation: the first scene (9) describes the search for inspiration by the sem priest. In this regard, the ritual sleeping with the subsequent dream vision is not a shamanic trance, but «deep meditation» performed by the sem priest to direct the making of the sculpture of the deceased. Scene 10, instead, concerns the guidelines of the sem priest to the artisans in order to make the sculpture: the animals and the shadows are thus metaphors to describe the different phases of the construction of the sculptures and not animal-guides [FischerElfert, 1998].

Fischer-Elfert's theory was the most accepted for all the 90s. However, with the advent of the new millennium, the shamanic interpretation started to gain recognition again. Why?

\subsection{Jan Assmann on Egyptian Shamanism and subsequent works}

Jan Assmanns's approach to so-called «personal piety» played a crucial role in Egyptology. And, although a number of recent (and less recent) works have strongly criticized both the terminology and the historical evolution of the Egyptian religion outlined by Assmann, his influence still remains undeniable.

For Assmann, non-royal people could not have direct contacts with the divine sphere. Only after important transformations which occurred with the advent of the New Kingdom - and strictly connected with the «Amarna revolution» - a special feeling of intimacy with the gods, strongly focused on personal destiny as expression of divine will, started to pervade textual sources relating to common people [Assmann, 2004].

This historical reconstruction belongs to a wider theoretical framework. In 1984 Assmann published Theologie und Frömmigkeiteinerfrühen Hochkultur. And, it is interesting to note that the label «shamanism» played a certain role in this work. Assmann's starting point is that Gottesnähe («nearness to God») is manifested in several ways (Dimensionen der Gottesnähe): the «local/cultic dimension», the «cosmos», the «verbal or mythic dimension», «ecstasy/shamanism», «mysticism/meditation», «history/ personal destiny»; and, each religion is characterized by a specific combination of such dimensions [Assmann, 2001, 153].

According to his interpretation, Ancient Egyptian civilization gave more importance to the first three ones: the «myth», the «cosmos» and the «cult». With regard to the «dimension of history», instead, this last one obtained a certain importance only after the advent of the New Kingdom, causing the rise of "personal piety» in pharaonic Egypt. Finally, we have only sparse samples of mysticism or shamanism [Assmann, 2001, 153 and ff.].

It is a concept that was further developed in 2001 with Tod und Jenseits. In fact in his opinion - for Egyptians the borders between the realm of humans and the realm of preternatural beings (gods and spirits of the dead) were not only rigorously separated, but also subject to a strict cultural control [Assmann, 2005, 15]. This means that every contact with the supernatural world had to be regulated and mediated by special rules. Thus, phenomena like «ecstatic trance» - that denote a direct and intimate connection with the preternatural sphere - could not be widespread:

The Egyptians believed that no one (with the possible exception of the king) was capable, during his life, of looking at the gods, of having visions, or of entering in 


\section{История религии / History of Religion}

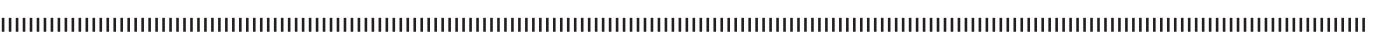

the realm of the gods. Prior to the Greco-Roman period, there are no traces of shamanism, prophecy, or mysticism in Egypt [Assmann, 2005, 78].

It is interesting to stress how this sentence was strongly criticized in all the main reviews of Tod und Jenseits [Morales, 2007; Lesko, 2007; Scalf, 2011]. Several scholars, in fact, questioned this assumption, underlining the role of ecstasy and intoxication in Egyptian festivals, the existence of certain mysticism recognizable in a number of passages from funerary literature and the possibility to have a direct contact with the spirits of the dead as testified by the so-called letters to the dead.

However, paradoxically, in Tod und Jenseits, with regard to the OMR scenes 9 and 10, Assmann is inclined to admit the peculiar traits of this texts, stressing that in this specific case it could be possible to speak about trance or meditation:

They are unique in the history of the Egyptian religion; they are an instance of trance or meditation, for which there are no parallels whatsoever in Egypt [Assmann, 2005, 313].

It is my opinion that the combination of these two factors - the criticisms to Assmann's assumption that in Ancient Egypt there was no trace of shamanism and the fact that he himself admits that OMR scenes 9 and 10 could be interpreted as a peculiar sample of «trance» - has led to the rise of several recent investigations into presumed Egyptian shamanism.

A number of recent studies show a renewed use of this label in a wider interpretative framework based on a kind of «survival theory». In these works «shamanism» is still considered a crucial trait of the archaic Egyptian religion (pre and proto-dynastic) [Morenz, 2014]; and, a number of religious aspects of historical times, like the OMR, as well as other rituals and myths, could be interpreted as fossils of these archaic practices. In a 2002 paper, Sigrid Hoedel-Hoenes argued that scenes 9 and 10, not only show shamanic traits, but also an undeniable, quite ancient African substrate, since the presence of the mantis and the spider finds numerous parallels in African traditional tales [HodelHoenes, 2002]. An article by Ludwig Morenz published in 2003 is clearly connected to Assmann's approach. In his opinion, an analysis of iconographic data dating back to the Thinite Age shows how in this historical phase religious practices interpretable as «shamanism» played a crucial role. On the other hand, for Morenz, Assmann's statement that shamanism had a secondary role in pharaonic Egypt is correct. In fact, with the rise of the centralized state the shamanic practices were marginalized, surviving only in certain traits of Egyptian religion. In his opinion, in fact, although the shamanic elements of the OMR could be questioned, certain descriptions of underworlds attested in the Coffin Texts and several elements of the Osirian myth seem to testify a certain shamanic substratum. Furthermore, in this regard, Morenz stresses that the presence of shamanic elements in «complex societies» is not exceptional, since - as Dodds and Meulihave shown - traces of shamanism could be found also in other ancient stratified and complex cultures [Morenz, 2003]. Sabine Neureiter, instead, strongly supports the previous shamanic interpretation of the OMR scenes 9 and 10. In her opinion, not only was shamanism a predominant trait during the pre- and proto-dynastic age, but it widely survived as «Teil des kollektiven Gedachtnisses» in historical times. Thus, several Egyptian religious phenomena could be interpreted as «shamanism», especially certain kinds of medical practices, but also the cult of deceased kings, the ancestor veneration and contacts with deceased spirits testified by the letters to the dead. Moreover, Neureiterdraws special attention to the OMR and other similar religious practices - such as the Tekenu Ritual and the Mysteries of Osiris celebrated in Abydos - all characterized by a «ritual sleeping» that - in her opinion should be interpreted as a shamanic trance [Neureiter, 2005].

\section{Conclusions and a new interpretation of the Opening of the Mouth ritual and the Tekenu Ritual in light of the label «ancestor worship»}

Juan Carlos Moreno Garcìa has recently argued that in Egyptology spiritual matters, like the study of religion, art and literature are privileged, while other more «materialist» subjects such as economy and sociology are neglected [Moreno Garcìa, 2015]. This statement is of course true. On the other hand, Egyptian religion cannot beexclusively considered a «spiritual matter», totally disconnected from its social, economic and juridical background. We also have to take into consideration another problem, 


\section{История религии / History of Religion}

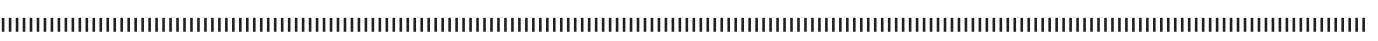

Jan Assmann is correct in underlining the special position of the Egyptian religion in the Western mindset. A certain idea of immortality and positive afterlife is surely indebted to Egyptians beliefs [Assmann, 2005, 11]. However, the risk is to overestimate certain traits that were reshaped in western traditions, and ignore other elements that could appear more «unusual» from our perspective. In other words, there was - and still is a peculiar combination of attitudes, which result in an ethnocentric bias, imbued with certain orientalistic stereotypes (first of all the so called ex oriente lux) [Weiss, 2015, 179 80]. And, these factors make an emic reconstruction of the Egyptian religion particularly difficult.

At some point in their history, the Egyptians surely believed in a positive afterlife, but it is also true that they believed in another kind of post mortem existence, based on a pact of mutual aid between the living and the dead [Schiavo, 2016]. This kind of belief which could be labeled as «ancestor worship» - has been underestimated by the specialists for a long time. And, in my opinion, the improper use of the label «shamanism» is strictly connected with this attitude.

Several studies have already shown the importance of ancestor veneration in the Egyptian religion [Demarée, 1983; Harrington, 2013; Donnat, 2014]. The spirits of the dead played a primary role already starting from the Old Kingdom [Czerwik, 2009]. And, the belief that the ancestral spirits could influence the everyday life of the living is an undeniable aspect of the Egyptian religion in all its historical phases [Harrington, 2013]. Thus, it is more reasonable to explain both funerary and mortuary rituals - like the OMR and the Tekenu ritual - in light of the label «ancestor worship», rather than «shamanism».

With regards to the OMR scenes 9 and 10, as already stressed, there was and still is a certain tendency to interpret them as the survival of an archaic ecstatic practice, during which the sculpture of the deceased had to be animated by a shamanic trance. The main argumentations could be summarized in three points:

1) The iconographic resemblance of one of the main performers of the ritual attested in historical times, the sem priest, to certain individuals depicted in pre and protodynastic objects and monuments;

2) The undeniable description of a special seclusion of the sem priest in a place called "Gold House»; the clear reference to a ritual sleeping (indicated with the Egyptian word $s \underline{d} r)$, during which the sem priest experiences a dream $(k d d)$ that consists in the vision of the deceased father «in all his forms». pantheon.

3) The absence of mythology and references to the traditional gods of the Egyptian

With regard to the «wearer of the leopard skins» attested in both pre and protodynastic times, several scholars underlined how this figure does not need to be necessarily identified with an archaic antecedent of the sem priest. For example Williams claimed that this person is always connected with scenes of violence and ritual killing of the enemies [Williams, 1997]. Instead, Kelder suggested that the "wearer of the leopard skin» could be identified with a woman, probably the daughter of the chief performing a special ritual action [Kelder, 2013]. Of course this is not the right place to solve such a spiny question. But, the crucial element to underline is that the leopard skin seems more related to the rise of the centralized state and social stratifications, rather than to an ancestral shamanic practice. Moreover, as argued by several scholars, the shamanic interpretation of prehistoric depictions of animals, or individuals wearing animal skins is surely misleading. It is mainly based on labile iconographic similarities with data attested in very specific geographical, cultural and historical contexts and, thus, it lacks any scientific foundation [Ambasciano, 2014, 164-165].

With regard to the second point, several data testified that in Egyptian beliefs the ritual sleeping $(\hat{s} \underline{d} r)$ and the dream $(k d)$ played a crucial role in the interactions between the living and the deceased. The letters to the dead, already attested during the Old Kingdom, were messages sent to ancestral spirits in order to solve existential crises (such as inheritance litigations, diseases and fertility problems) [Donnat, 2014]. And, it is interesting that in two of these missives the dream is described as a special «space» in which human beings could interact with the spirits of the dead [Szpakowska, 2003, 19 and ff.]. Furthermore, the ritual sleeping is not attested only in the OMR. A similar 
practice was also performed in another obscure funerary ceremony, the Tekenu ritual, during which a person wrapped in a piece of leather $\left(m s^{\prime} k^{3}\right)$ had to spend the night ( $\left.s^{\prime} d r\right)$ inside the tombs of the deceased [Delgado, 2011]. Something similar (always expressed by the term $s \underline{d} d r)$ is attested for the Haker-festival held in Abydos in the course of the Osirian Mysteries. It was a special commemoration in order to praise the dead, during which both Osiris and the deceased could obtain a vindication against their enemies [Végh, 2011].

In all these cases we face a particular kind of sleeping that allows a special contact with the dead. However, both the terms «trance» and «meditation» found in scientific literature are rather misleading, suggesting a core of beliefs that cannot fit with ancient Egyptian civilization. This kind of ritualistic sleeping had in fact a meaning that can only be understood in light of the context of the Egyptian society, with its specific moral and juridical norms of conducts, which were strongly connected with the veneration of the ancestors.

Several scholars stressed that the OMR scenes 9 and 10 show a «pre-classic», «archaic» or «shamanic»substrate because of the absence of explicit references to the traditional gods, while the main focus is given to the relationship between the living and the dead, with special attention to the father-son bond.

On the other hand, the OMR is not the only Egyptian document showing these peculiar traits. Moreover, it is possible to sustain that the absence of explicit mythological references and the importance given to the interaction between the living and the dead is one of the distinctive characteristic of the data relating to Egyptian ancestor worship. For example, with regard to the letters to the dead Michael O'Donoghue sustained that: «References to the gods in the letters are remarkably sparse. When the gods are mentioned they are rather secondary actors in the drama. They seem to be very similar to the otiose god discussed by Mircea Eliade» [O'Donoghue, 1999, 89]. The same traits characterize another important group of documents concerning the Egyptian ancestors cult, a restricted collection of Coffin Texts spells focused on the post mortem survival of the family connections, including a group (30-41) mainly centered on the relationship between the dead father and his living son. Harco Willems, in fact, described these texts in the following way: «[...] there is a small collection of spells without mythology $[\ldots]$. What matters most in these texts is the relationship between the living and the dead, while gods show a secondary role» [Willems, 2014, 183].

Assuming that both the OMR and the Tekenu ceremony were religious phenomena connected with Egyptian ancestor worship, rather than the expression of an archaic shamanic practice, several considerations can be made. First, we are not facing ceremonies that were only focused on the rebirth of the deceased in the afterlife, but with a kind of rite of passage. As stressed by Robert Hertz [Hertz, 1960, 69 and ff.] and Arnold Van Gennep [Van Gennep, 1960, 92], articulated burial ceremonies - like, for example, the so called «secondary burials» - play a special role in transforming a common dead person into an ancestor. And, it would not be wrong to hypothesize something similar for the rituals taken into consideration here.

H. Willems' analysis on Coffin Texts spells 30-41 stressed that this group of spells could be considered as a complex ritual with two main aims. The first one was to establish the role of the deceased father as a benevolent ancestor; while, the second one was to inaugurate (or reinforce) the role of the living son as the new leader of the household, assuming the social position of the dead father [Willems, 2001]. The same double function could be extended also to the OMR, especially with regard to scenes 9 and 10. The main performer of the ritual, the sem priest, was in fact identified with the eldest son of the deceased. It is not clear if the sem was a professional ritualist acting in the name of the eldest son, or if the ritual was effectively performed by the main heir [Assmann, 2005, 313]. But, what is really important to underline is that the ceremony affectednot only the deceased, but also the ritualist/living son. In effect, the seclusion of the sem priest in the Gold House, the sleeping ritual and the vision of the dead father during a dream fit quite well with a rite of passage performed to transmute the legitimate heir into the new chief of the typical Egyptian extended family.

This last observation could be confirmed by a comparison with Egyptian customary laws concerning inheritance. In fact, it is well known that for the Egyptians to take care 


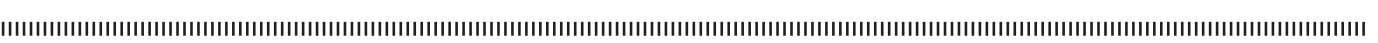

of both funerary and mortuary rituals was a substantial step in order to be proclaimed the legitimate heir of the real estate belonging to the deceased [Lippert, 2013]. Moreover, we have to assume that in the Egyptian mindset the concept of «real estate» did not include only houses and land, but also the servants who had to take care of such goods [Lippert, 2013]. Thus in other words, to inherit real estate from a deceased family member meant becoming the new chief of the family depending on these goods.

Regarding the Tekenu ritual, although we have very little information about it, a similar interpretation can be made. The ceremony involving the Tekenu is known only through depictions inside the tombs, and the identification of the Tekenu with a person acting as ritualist, rather than with an obscure object, is very recent [Reeder, 1994; Delgado, 2011]. In fact, the Tekenu is often represented as a shapeless sack on a sledge that is about to be transported inside the tomb; while, only on rare occasions he undeniably shows the shape of a human being wrapped in a skin that is clearly indicated in the captions with the term msk A. Finally, in very few testimonies dating back to the New Kingdom it appears with the shape of a man wrapped in the mskA-skin while sleeping on a couch, probably involved in a ritual quite similar to the one of the OMR scenes 9 and 10 [Paraskeva, 2013, 14 and ff.]. However, in this specific case, we have no information regarding the identity of the ritualist. It is impossible to know if he was a professional, the eldest son or another relative of the deceased [Paraskeva, 2013, 17 and ff.]. On the other hand, it is surely suggestive that in an Old Kingdom letters to the dead, the so-called Cairo Linen, a skin- $m s^{\prime} k^{3}$ seems to play a crucial role in complicated inheritance litigation. A widower, Ireti, asks the spirit of her deceased husband to protect their son, Iy the young, from an antagonist family that illegitimately took possession of his inheritance:

This is a reminder of when the messenger of Behesti came for the mśk’-skin. I was sitting at your bedside, when they caused Ireti's son, Iy, to be summoned because of the juridical procedure with the messenger of Behesti. And you said: "May the wooden of my bed rot if the son of a man is parted from his furniture!» [for the translation Cf. Schiavo, 2013, 132].

Regarding the meaning of the term $m s^{\prime} k^{3}$ in this document several hypotheses have been made. For Gardiner and Sethe it was a metaphor to indicate the couch on which the husband of the writer was lying [Gardiner and Sethe, 1928, 1-3 and 13-17]. For Willems, instead, it was a real piece of leather, disputed between the two families because of its

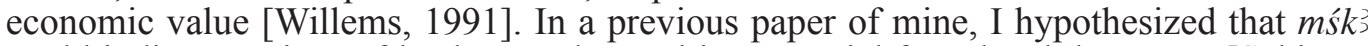
could indicate a piece of leather used as writing material for a legal document [Schiavo, 2013]. Finally Donnat, argued that the $m s^{\prime} k^{3}$-skin had to have a symbolic and ritual meaning connected with the possibility to obtain the inheritance [Donnat, 2009]. Donnat, in this regard, has not identified a specific rite. On the other hand, it could be suggestive to identify the mskA-skin cited in the Cairo Linen with the one involved in the Tekenu ritual. Accepting this last hypothesis, the Tekenu ritual could be interpreted - as the OMR and the ritual concerning the Coffin Texts spells 30-41 - as a special rite of passage performed for both the deceased (who has to attain the status of ancestor, or rebirth in the afterlife, and the living son/ritualist who has to obtain not only the inheritance, but also the social status of the dead father. Also in this case, therefore, we are not facing the survival of an ancient ecstatic trance.

The Tekenu ceremony, as well the OMR scenes 9 and 10 and the rituals connected with the Coffin Texts spells 30-41 could be explained only in the contexts of ancient Egyptian ancestor worship. And it is undeniable that this kind of beliefs was tightly intertwined with several sociological aspects, as well with a number of economic and juridical traits of the Egyptian society.

\section{Библиографический список}

1. Ambasciano, L. Sciamanesimo Senza Sciamanesimo. Le radici intellettuali del modello sciamanico di Mircea Eliade. Evoluzionismo, psicanalisi, te(le)ologia / L. Ambasciano. - Roma, 2014.

2. Assmann, J. Totenkult / J. Assmann // W. Helckand E. Otto (eds.), Lexikon der Ägyptologie VI. Wiesbaden, 1986. - S. 659-664. 


\section{История религии / History of Religion}

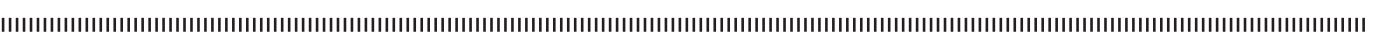

3. Assmann, J. The search for god in ancient Egypt / J. Assmann. - Ithaca, 2001. English translation of: Assmann, J. Ägypten: Theologie und Frömmigkeit einer frühen Hochkultur / J. Assmann. Stuttgart, 1984.

4. Assmann, J. Theological responses to Amarna / J. Assmann // J. Assmann (ed.), Egypt, Israel, and the ancient Mediterranean world: studies in honor of Donald B. Redford. - Leiden and Boston, 2004. - S. 179-191.

5. Assmann, J. Death and salvation in ancient Egypt / J. Assmann. - Ithaca, 2005. English translation of: Assmann, J. Tod und Jenseits im alten Ägypten. - München, 2001.

6. Baines, J. Practical religion and piety / J. Baines // Journal of Egyptian Archaeology. - 1987. № 73. - S. 79-98.

7. Czerwik, D. Inek Akh in the light of the tomb inscriptions from the VIth Dynasty / D. Czerwik // Popielska-Grzybowska Joanna, Olga Białostocka, and Jadwiga Iwaszczuk (eds), Proceedings of the Third Central European Conference of Young Egyptologists. Egypt 2004: perspectives of research. Warsaw 12-14 May 2004, 37-47. - Pułtusk, 2009.

8. Delgado, S. A contribution to the study of the tekenu and its role in Egyptian funerary ritual / S. Delgado // Zeitschrift für ägyptische Sprache und Altertumskunde. -2011. - № 138. - S. 150-16.

9. Demarée, R. J. AkhIqeren Ra Stelae: on ancestor worship in ancient Egypt / R. Demarée. Leiden, 1983.

10. Donnat, S. Le rite comme seul référent dans les lettres aux morts: nouvelle interprétation du début du CairoText on Linen / S. Donnat // Bulletin de l'Institut Français d'Archéologie Orientale. 2009. - № 109. - S. 61-93.

11. Donnat, S. Écrire à ses morts: enquête sur un usage rituel de l'écrit dans l'Égypte pharaonique / S. Donnat. - Grenoble, 2014.

12. Fischer-Elfert, H.-W. Die Vision von der Statue im Stein: Studien zum altägyptischen Mundöffnungsritual / H.-W. Fischer-Elfert. - Heidelberg, 1998.

13. Gardiner, A.H. Egyptian Letters to the Dead mainly from the Old and Middle Kingdoms A.H. Gardiner, K.H. Sethe. - London, 1928.

14. George, B. Zu den altägyptischen Vorstellungen vom Schatten als Seele / B. George. - 1970.

15. Harrington, N. Living with the dead ancestor worship and mortuary ritual in ancient Egypt $/$ N. Harrington. - Oxford, 2012.

16. Helck, W. Schamane und Zauberer/W. Helck // Mélanges Adolphe Gutbub. - Montpellier, 1984.

17. Helck, W. Untersuchungen zur Thinitenzeit / W. Helck. - Wiesbaden, 1987.

18. Hertz, R. A contribution to the study of the collective representation of death / R. Hertz // Hertz R. Death and The Right Hand. - London, 1960.

19. Hodel-Hoenes, S. Afrikanisches Gedankengut im Mundöffnungsritual / S. Hodel-Hoenes // Mélangesofferts à Edith Varga: le lotusqui sort de terre. - S. 185-196.

20. Kelder, J. Narmer, Scorpion, and the representation of the early Egyptian court / J. Kelder // Origini: preistoria e protostoria delle civiltà antiche. - 2013. - № 35. - S. 143-156.

21. Kopytoff, I. Ancestors as elders in Africa / I. Kopytoff // Africa: journal of the International African Institute. - 1971. - № 41/2. - S. 129-142.

22. Lesko, L.H. Death and Salvation in Ancient Egypt (Book review) / L.H. Lesko // American Historical Review. - 2007. - № 112/3. - S. 962.

23. Lippert, S. Inheritance / S. Lippert // UCLA Encyclopedia of Egyptology. - Los Angeles, 2013

[Электронный ресурc]. - URL: http://www.escholarship.org/uc/item/30h78901.

24. Morales, A.J. Death and Salvation in Ancient Egypt (Book review) / A.J. Morales // The Journal of the American Oriental Society. - 2007. - № 127/1. - № 74 .

25. Moreno Garcìa, J.C. The cursed discipline? The peculiarities of Egyptology at the turn of the twenty-first century / J.C. Moreno Garcì // W. Carruthers (ed.), Histories of Egyptology: interdisciplinary measures. - New York and London, 2015.

26. Morenz, L.D. Schamanismus in der Frühzeit Ägyptens? / L.D. Morenz // Archiv für Religionsgeschichte. - 2003. - № 5. - S. 212-226.

27. Morenz, L.D. Medienevolution und die Gewinnung neuer Denkräume: das frühneolithische Zeichensystem (10./9. Jt. v. Chr.) und seine Folgen / L.D. Morenz. - Berlin, 2014.

28. Moret, A. Mystères égyptiens / A. Moret. - Paris, 1931.

29. Neureiter, S. Schamanismus im Alten Ägypten / S. Neureiter // Studien zur Altägyptischen Kultur. - 2005. - № 33. - S. 281-330.

30. O'Donoghue. The "Letters to the Dead" and Ancient Egyptian Religion / O'Donoghue // Bulletin of the Australian Centre for Egyptology. - 1999. - № 10. - S. 87-104.

31. Otto, E. Das Ägyptische Mundöffnungsritual / E. Otto. - Vol. II. - Wiesbaden, 1960.

32. Paraskeva, K. The enigmatic "tekenu". An iconographical analysis of "tekenu" in tombs from the Old Kingdom to the Late Period. Unpublished master dissertation / K. Paraskeva. - Leiden, 2013 [Электронный ресурc]. - URL: http://hdl.handle.net/1887/21625. 


\section{История религии / History of Religion}

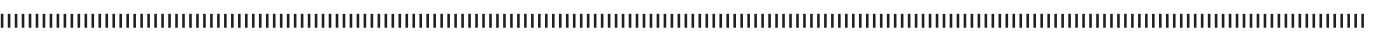

33. Reeder, G. A rite of passage: the enigmatic tekenu in ancient Egyptian funerary ritual / G. Reeder // KMT. - 1994. - № 5. - S. 53-59.

34. Scalf, F. Death and Salvation in Ancient Egypt (Book review) / F. Scalf // Journal of Near Eastern Studies. - 2011. - № 70/1. - S. 124.

35. Schiavo, R. Tradizione e innovazioni nella religione egizia. I limiti della teoria della 'democratizzazione dell'Aldilà' e l'importanza del culto degli antenati egizio / R. Schiavo // Studi Epigrafici e Linguistici. - 2016. - № 34. - S. 1-15.

36. Schiavo, R. Sulla possibile funzione giuridica di alcune lettere ai morti / R. Schiavo // Aegyptus. 2013. - № 93. - S. 125-145.

37. Szpakowska, K. Behind closed eyes: dreams and nightmares in ancient Egypt / K. Szpakowska.Swansea, 2003.

38. Van Gennep, A. The Rites of Passage / A. Van Gennep. - London, 1960.

39. Végh, Z. Counting the dead: some remarks on the Haker-Festival / Z. Végh // Current research in Egyptology 2009: proceedings of the tenth annual symposium. - Oxford: University of Liverpool, 2009, 2011. - S. 145-156.

40. Weiss, L. Religious Practice at Deir el-Medina / L. Weiss. - Leiden, 2015.

41. Wildung, D. Ahnenkult / D. Wildung // Helckand W., Otto E. (eds.). Lexikon der Ägyptologie Vol. I. - Wiesbaden, 1975. - S. 111.

42. Willems, H. The social and ritual context of a mortuary liturgy of the Middle Kingdom (Cofin Texts spells 30-41) / H. Willems // Willems H. (ed.). Social aspects of funerary culture in the Egyptian Old and Middle Kingdoms: proceedings of the international symposium held at Leiden University 6-7 June, 1996. - Leuven, 2001. - S. 253-372.

43. Willems, H. Historical and archaeological aspects of Egyptian funerary culture: religious ideas and ritual practice in Middle Kingdom elite cemeteries / H. Willems. - Leiden and Boston, 2014.

44. Williams, B.B. The wearer of the leopard skin in the Naqada period / B.B. Williams // Phillips J. (ed.) Ancient Egypt, the Aegean, and the Near East: studies in honour of Martha Rhoads Bell. - San Antonio, 1997. - S. 483-496.

Текст поступил в редакиию 25.12.2017.

\section{References}

1. Ambasciano L. Shamanism without Shamanism. The Intellectual Roots of the Shamanist Model of Mircea Eliade. Evolutionism, psychoanalysis, te(le) ologia [Sciamanesimo Senza Sciamanesimo. Le radici intellettuali del modello sciamanico di Mircea Eliade. Evoluzionismo, psicanalisi, te(le)ologia]. Roma, 2014 (in Italian).

2. Assmann J. Dictionary of Egyptology VI [Lexikon der Ägyptologie VI]. Wiesbaden, 1986, pp. 659-664 (in German).

3. Assmann J. The search for god in ancient Egypt. Ithaca, 2001 (in English).

4. Assmann J. Egypt, Israel, and the ancient Mediterranean world: studies in honor of Donald B. Redford. Leiden and Boston, 2004, pp. 179-191 (in English).

5. Assmann J. Death and salvation in ancient Egypt. Ithaca, 2005 (in English).

6. Baines J. Journal of Egyptian Archaeology. 1987, no. 73, pp. 79-98 (in English).

7. Czerwik D. Proceedings of the Third Central European Conference of Young Egyptologists. Egypt 2004: perspectives of research. Warsaw 12-14 May 2004, 37-47. Pułtusk, 2009 (in Polish).

8. Delgado S. Journal for the Egyptian Language and Archeology [Zeitschrift für ägyptische Sprache und Altertumskunde]. 2011, no. 138, pp. 150-16 (in English).

9. Demarée R. J. The 3h Ir N Rc-Stelae: On Ancestor Worship in Ancient Egypt. Leiden, 1983 (in English).

10. Donnat S. Newsletter of the the French Institute for Oriental Archaeology [Bulletin de l'Institut Français d'Archéologie Orientale]. 2009, no. 109, pp. 61-93 (in French).

11. Donnat S. Écrire à ses morts: enquête sur un usage rituel de l'écrit dans l'Égypte pharaonique. Grenoble, 2014 (in French).

12. Fischer-Elfert H.-W. The Vision of the Statue in Stone: Studies of the Ancient Egyptian Opening of the Mouth Ritual [Die Vision von der Statue im Stein: Studien zum altägyptischen Mundöffnungsritual]. Heidelberg, 1998 (in German).

13. Gardiner A.H., Sethe K.H. Egyptian Letters to the Dead mainly from the Old and Middle Kingdoms. London, 1928 (in English).

14. George B. To the Ancient Egyptian Images of Shade as the Soul [Zu den altägyptischen Vorstellungen vom Schatten als Seele]. 1970 (in German).

15. Harrington N. Living with the dead ancestor worship and mortuary ritual in ancient Egypt. Oxford, 2012 (in English).

16. Helck W. Mélanges Adolphe Gutbub. Montpellier, 1984 (in German).

17. Helck W. Untersuchungen zur Thinitenzeit. Wiesbaden, 1987 (in German).

18. Hertz R. Death and The Right Hand. London, 1960 (in English). 


\section{История религии / History of Religion}

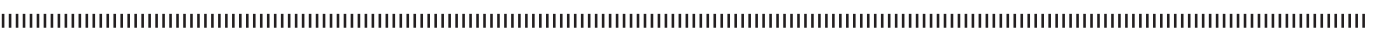

19. Hodel-Hoenes S. Mélangesofferts à Edith Varga: le lotusqui sort de terre, pp. 185-196 (in German).

20. Kelder J. The Origins: Prehistory and Protostoria of ancient Civilisations [Origini: preistoria e protostoria delle civiltà antiche]. 2013, no. 35, pp. 143-156 (in Italian).

21. Kopytoff I. Africa: Journal of the International African Institute. 1971, no. 41/2, pp. 129-142 (in English).

22. Lesko L.H. American Historical Review. 2007, no. 112/3, p. 962 (in English).

23. Lippert S. Inheritance. UCLA Encyclopedia of Egyptology. Los Angeles, 2013. Available at: http://www. escholarship.org/uc/item/30h78901.

24. Morales A.J. The Journal of the American Oriental Society. 2007, no. 127/1, p. 74 (in English).

25. Moreno Garcìa J.C. Histories of Egyptology: interdisciplinary measures. New York and London, 2015 (in English).

26. Morenz L.D. Archive of Religious Studies [Archiv für Religionsgeschichte]. 2003, no. 5, pp. 212-226 (in German).

27. Morenz L.D. Media evolution and the production of new mental rooms: Early Neolithic sign system (10-9 million years ago) and ist results [Medienevolution und die Gewinnung neuer Denkräume: das frühneolithische Zeichensystem (10./9. Jt. v. Chr.) und seine Folgen]. Berlin, 2014 (in German).

28. Moret A. Egyptian mysteries [Mystères égyptiens]. Paris, 1931 (in French).

29. Neureiter S. Studies of Ancient Egyptian Culture [Studien zur Altägyptischen Kultur]. 2005, no. 33, pp. 281-330 (in German).

30. O’Donoghue. Bulletin of the Australian Centre for Egyptology. 1999, no. 10, pp. 87-104 (in English).

31. Otto E. The Egyptian Opening of the Mouth Ritual [Das Ägyptische Mundöffnungsritual]. Vol. II. Wiesbaden, 1960 (in German).

32. Paraskeva K. The enigmatic "tekenu”. An iconographical analysis of "tekenu” in tombs from the Old Kingdom to the Late Period. Unpublished master dissertation. Leiden, 2013. Available at: http://hdl.handle. net/1887/21625 (in English).

33. Reeder G. KMT. 1994, no. 5, pp. 53-59 (in English).

34. Scalf F. Journal of Near Eastern Studies. 2011, no. 70/1, p. 124 (in English).

35. Schiavo R. Epigraphic and Linguistic Studies [Studi Epigrafici e Linguistici]. 2016, no. 34, pp. 1-15

(in Italian).

36. Schiavo R. Aegyptus [Egypt]. 2013, no. 93, pp. 125-145 (in Italian).

37. Szpakowska K. Behind closed eyes: dreams and nightmares in ancient Egypt. Swansea, 2003 (in English).

38. Van Gennep A. The Rites of Passage. London, 1960 (in English).

39. Végh Z. Current research in Egyptology 2009: proceedings of the tenth annual symposium. Oxford: University of Liverpool, 2009, 2011, pp. 145-156 (in English).

40. Weiss L. Religious Practice at Deir el-Medina. Leiden, 2015 (in English).

41. Wildung D. Dictionary of Egyptology [Lexikon der Ägyptologie]. Eds. Helckand W., Otto E. Vol. I. Wiesbaden, 1975, p. 111 (in German).

42. Willems H. Social aspects of funerary culture in the Egyptian Old and Middle Kingdoms: proceedings of the international symposium held at Leiden University 6-7 June, 1996. Leuven, 2001, pp. 253-372 (in English).

43. Willems H. Historical and archaeological aspects of Egyptian funerary culture: religious ideas and ritual practice in Middle Kingdom elite cemeteries. Leiden and Boston, 2014 (in English).

44. Williams B.B. Ancient Egypt, the Aegean, and the Near East: studies in honour of Martha Rhoads Bell. Ed. Phillips J. San Antonio, 1997, pp. 483-496 (in English). 